\title{
Pengaruh perceived organizational support terhadap organizational citizenship behavior karyawan di hotel four points by sheraton bali seminyak
}

\author{
I Wayan Adi Pariarta ${ }^{1)}$, Fanny Maharani Suarka ${ }^{2)}$, Putu Ratih Pertiwi ${ }^{3)}$ \\ Program Studi Diploma IV Pariwisata, Fakultas Pariwisata, Universitas Udayana \\ Jalan DR. R. Goris No. 7, Denpasar, Bali. \\ Email : adipariartha@gmail.com
}

\begin{abstract}
Abstrak
Penelitian ini didasari atas masih adanya kekurangan dalam Prilaku OCB karyawan di Hotel Four Points By Sheraton Bali Seminyak, ditunjukan dengan permasalahan turnover yang melebihi $10 \%$ dan prilaku OCB yang masih kurang meliputi : ma sih adanya hasil pekerjaan yang dibawah standar, $\mathrm{k}$ u rangn ya partisip asi sukarela dari karyawan, dan masih a danya keluhan karyawan terkait kondisi kerja. Tujuan dari penelitian in $\mathrm{i}$ a dalah untuk mengetahui pengaruh Perceived Organizational Support terhadap Organizational Citizenship kary awan diHotelFour Points By Sheraton Bali Seminyak. Sumber data yang digunakan adalah data prim er dan sekunder. Jenis data menggunakan data kualitatif dankuan titatif. Teknik pengu mpulan data yaitu observasi, wa wancara, kusioner, studi pustaka dan dokumen tasi. Responden dalam pen elitia $n$ a dalah karyawan tetap dan kontrak, denganjumlah sampel 79 orang. Teknik a nalisis data yang digu nakan y aitu : Analisis Skala Likert, Analisis Regresi Linear Sederhana, Uji T, Koefisien Korelasi, dan Koefisien Determinasi. Hasil Uji Hipotesis Parsial menunjukan bahwa variabel POS berpengaruh positif dan signifikan terhadap variabel $O C B$ dengan nilait hitung 7,539. Koefisien korelasi hasil a nalisa regresi a dalah 0,643 yang menunjukan korelasi kuat variabel POS terhadap OCB. Hasil Koefisien Determina si menunjukan bahwa variabel POS mampu mempengaruhi variabel OCB sebesar 40,5\%, dan sisanya sebesar 59,5\% dipeng aruh $\mathrm{i}$ oleh faktor lain.
\end{abstract}

Kata Kunci : Perceived Organizational Support, Orga nizational Citizenship Behavior.

\begin{abstract}
This research is conducted based on em ployee OCB behavior that still lack at Four Points By Sheraton Ba li Seminyak Hotel, indica te d by turnover ra te exceeding $10 \%$ and OCB behavior that need improvement include: work results that are below standard, la ck of voluntary participation from employees, and emplo yee complaints regarding work conditions. The aim of this research is to determine the effect of POS towards employee's OCB at Four Points By Sheraton Bali Seminyak. Data sources that used are primary and secondary data. The type of data used in this research a re qualitative and quantitative data. Da ta collection techniques are observation, questionnaire, litera ture study, and documentation. Respondent on this re se arch a re permanentand contract employee with sample size of 79 persons. Da ta a nalysis technique in this research are : Likert Scale Analysis, Simple Linear Regression, T test, Correlation Coefficient, Determination Coefficient. PartialHy pothesis Test Results show that the POS variable has a positive and significant effect on the OCB variable with a $t$ value of 7.539. The correlation coefficient results of the regression analy sis is 0.643 which shows the strong correlation of $\mathrm{POS}$ variables with OCB. Determination coefficientresults show that the POS variable is able to influence the OCB variable by $40.5 \%$, and the remaining $59.5 \%$ is influenced by other factors
\end{abstract}

Keywords : Perceived Organizational Support, Orga nizationalCitizenship Behavior

\section{PENDAHULUAN}

Four Points By Sheraton Bali Seminyak adalah hotel bintang 4 yang terletak di Jl. Cendrawasih, Petitenget, Seminyak, Kecamatan Kuta Utara. Hotel ini pertama kali dibangun pada tahun 2012 dengan nama Vasanthi Kuta Resort, dan dikelola oleh perusahaan Topotel. Tanggal 1 Juli 2016 manajemen hotel ini diambil alih oleh Perusahaan Marriott International dan turut serta merubah nama hotel menjadi Four Points By Sheraton Bali Seminyak. Letak yang strategis di kawasan Seminyak membuat hotel ini memiliki tingkat persaingan pasar yang cukup tinggi, adapun beberapa pesaing utama hotel pada kelas bintang 4 dan bintang 5 di kawasan Seminyak yaitu : 
Alila Seminyak, Maxone Hotels \& Co, Maison At C, Devinsky Seminyak, dan Hotel Indigo Bali Seminyak. Persaingan ini turut serta mempengaruhi tingkat hunian kamar yang fluktatif seperti yang terlihat pada Tabel 3

Tabel 1 Rata-Rata Tingkat Hunian Kamar Hotel Four Points By Sheraton Bali Seminyak Tahun $2016-2018$

\begin{tabular}{cccc}
\hline No & Tahun & $\begin{array}{c}\text { Persentase } \\
\text { Tingkat Hunian } \\
\text { Kamar (\%) }\end{array}$ & Pertumbuhan \\
\hline 1 & 2016 & $86,06 \%$ & - \\
\hline 2 & 2017 & $82,71 \%$ & $-4,35 \%$ \\
\hline 3 & 2018 & $84,27 \%$ & $1,79 \%$ \\
\hline
\end{tabular}

Sumber : Dokumen Sales \& Marketing (2019)

Berdasarkan Tabel 1 dapat diketahui pada tahun 2016 persentase rata-rata kamar yang terhuni adalah 86,06 \%, kemudian pada tahun 2017 mengalami penurunan sebesar 4,35\% menjadi 82,71 $\%$, dan pada tahun 2018 mengalami peningkatan sebesar 1,79\% sehingga menjadi 84,27\%. Tingkat persaingan ini membuat pihak hotel harus mampu untuk memberikan pelayanan yang terbaik kepada wisatawan, dan pelayanan yang baik kepada wisatawan sangat bergantung pada kinerja setiap sumber daya manusia yang ada. Utami (2012) dalam Dharmawiguna (2015) mengemukakan bahwa potensi setiap sumber daya manusia yang ada di dalam suatu perusahaan harus dapat dimanfaatkan dengan sebaik-baiknya sehingga mampu memberikan output yang optimal. Karyawan menurut Purwadarminta (1986) adalah orang yang bekerja pada suatu lembaga, kantor, perusahaan, dengan mendapatkan gaji (upah). Adapun data karyawan di Four Points By Sheraton Bali, Seminyak dapat dilihat pada Tabel 2

Tabel 2 Jumlah Karyawan Tetap Dan Kontrak Four Points By Sheraton Bali, Seminyak Pada Bulan Mei 2019

\begin{tabular}{|c|c|c|c|c|c|}
\hline \multirow{2}{*}{ Departemen } & \multicolumn{2}{|c|}{ Karyawan } & \multicolumn{2}{|c|}{ Jenis Kelamin } & \multirow{2}{*}{ Total } \\
\hline & Tetap & Kontrak & Laki-Laki & Perempuan & \\
\hline $\begin{array}{l}\text { Admin \& General } \\
\text { (General } \\
\text { Manager) }\end{array}$ & 1 & - & 1 & - & 1 \\
\hline$I T$ & 1 & 1 & 2 & 0 & 2 \\
\hline Accounting & 8 & 1 & 4 & 5 & 9 \\
\hline Human Resources & 2 & - & 1 & 1 & 2 \\
\hline Engineering & 7 & 3 & 10 & - & 10 \\
\hline $\begin{array}{l}\text { Food \& Beverage } \\
\text { Kitchen } \\
\text { Department }\end{array}$ & 9 & 5 & 10 & 4 & 14 \\
\hline $\begin{array}{l}\text { Food \& Beverage } \\
\text { Service } \\
\text { Department }\end{array}$ & 8 & 4 & 7 & 5 & 12 \\
\hline $\begin{array}{l}\text { Front Office } \\
\text { Department }\end{array}$ & 8 & 4 & 8 & 4 & 12 \\
\hline
\end{tabular}




\begin{tabular}{lccccc}
\hline $\begin{array}{l}\text { Housekeeping } \\
\text { Department }\end{array}$ & 12 & 3 & 14 & 1 & 15 \\
\hline $\begin{array}{l}\text { Loss Prevention } \\
\text { Sales \& }\end{array}$ & 3 & - & 2 & 1 & 3 \\
$\begin{array}{l}\text { Deparketing } \\
\text { Department }\end{array}$ & 2 & 4 & 2 & 4 & 6 \\
\hline Spa & 3 & 1 & - & 4 & 4 \\
\hline Revenue & 1 & 1 & - & 2 & 2 \\
\hline Total & 65 & 27 & 61 & 31 & 92 \\
\hline
\end{tabular}

Sumber : HRD Four Points By Sheraton Bali Seminyak (2019)

Berdasarkan Tabel 2 dapat dilihat bahwa jumlah total karyawan yang ada di Four Points By Sheraton Bali, Seminyak pada bulan Mei 2019 yaitu sebanyak 92 orang yang terdiri dari 65 karyawan tetap dan 27 karyawan kontrak. Berdasarkan data diatas juga dapat diketahui bahwa jumlah karyawan laki-laki berjumlah 61 orang dan karyawan perempuan 31 orang. Pentingnya peran karyawan membuat perusahaan perlu untuk mengelola karyawan dengan sebaik mungkin agar mampu untuk mempertahankan kualitas pelayanan yang baik dan memberikan kontribusi lebih bagi perusahaan. Perilaku karyawan dalam memberikan kontribusi lebih untuk perusahaan biasa dikenal dengan sebutan Organizational Citizenship Behavior (OCB).

Organizational Citizenship Behaviour oleh Greenberg dan Baron (2003) didefinisikan sebagai perilaku dimana seorang karyawan melakukan sesuatu di luar aturan formal sesuai dengan harapan perusahaan sebagai bentuk kontribusi terhadap kesejahteraan organisasi. Organ (1988) dalam Zhang (2011) mengemukakan lima indikator yang menentukan Organizational Citizenship Behavior, yaitu :

1. Altrusm, adalah perilaku dalam membantu karyawan lain dalam pekerjaan

2. Courtesy, adalah jujur dan ramah dalam usaha mencegah konflik kerja

3. Conscientiousness, adalah inisiatif memberikan hasil yang melebihi persyaratan perusahaan.

4. Civic Virtue, keinginan untuk terlibat dan ikut bertanggung jawab dalam kegiatan organisasi serta peduli pada kelangsungan organisasi

5. Sportsmanship, mampu mentoleransi situasi yang kurang ideal di tempat kerja tanpa mengeluh.

Ketika kelima indikator tersebut terpenuhi maka Organizational Citizenship Behavior yang terbentuk pada karyawan akan mampu memberikan keuntungan bagi perusahaan. Podsakoff \& Blume (2009) dalam Zhang (2011) menyebutkan bahwa adanya Organizational Citizenship Behavior akan memberikan keuntungan bagi perusahaan karena dapat meningkatkan produktivitas, efisiensi dan kepuasan pelanggan, serta mengurani biaya dan turnover.

Organizational Citizenship Behavior merupakan faktor yang perlu diperhatikan perusahaan agar mampu untuk mengoptimalkan setiap sumber daya manusia yang ada dalam meraih tujuan. Namun, pada kenyataannya masih terdapat permasalahan yang terjadi terkait Organizational Citizenship Behavior pada karyawan Four Points By Sheraton Bali Seminyak. Hal ini dapat dilihat dari tingkat turnover yang terjadi dari tahun 2016 sampai 2018 di Hotel Four Points By Sheraton Bali Seminyak. Menurut Supriyanto (2007) dalam Julanda (2018) turnover merupakan masalah 
serius bagi perusahaan apabila sudah melebihi $10 \%$ pertahun. Adapun tingkat turnover karyawan di Four Points By Sheraton Bali, Seminyak dapat dilihat pada Tabel 3

Tabel3 Tingkat Turnover Karyawan Four Points By Sheraton Bali Seminyak Tahun 2016-2018

\begin{tabular}{cccccc}
\hline Tahun & $\begin{array}{c}\text { Karyawan } \\
\text { Awal Tahun }\end{array}$ & Masuk & Keluar & $\begin{array}{c}\text { Karyawan Akhir } \\
\text { Tahun }\end{array}$ & $\begin{array}{c}\text { Persentase } \\
\text { Turnover } \\
(\%)\end{array}$ \\
\hline 2016 & 115 & 15 & 22 & 108 & 6.28 \\
\hline 2017 & 108 & 12 & 17 & 103 & 4.74 \\
\hline 2018 & 103 & 14 & 25 & 92 & 11.28 \\
\hline
\end{tabular}

Sumber : Dokumen HRD Four Points By Sheraton Bali Seminyak (2019).

Berdasarkan tabel 3 diatas dapat diketahui tingkat turnover karyawan Four Points By Sheraton Bali Seminyak dari tahun 2016 sampai 2018. Walaupun tingkat turnover karyawan Hotel Four Points By Sheraton Bali Seminyak menurun pada tahun 2017 dari tahun sebelumnya yaitu tahun 2016 dengan persentase 6,28 persen, tetapi pada tahun 2018 tingkat turnover di hotel tersebut kembali meningkat secara drastis hingga mencapai 11,28 persen. Turnover karyawan di Four Points By Sheraton Bali Seminyak telah mencapai tingkat yang mengkhawatirkan pada tahun 2018 dikarenakan persentasenya yang sudah melebihi $10 \%$ pertahun. Tingginya tingkat turnover yang terjadi memberikan gambaran mengenai permasalahan Organizational Citizenship Behavior karyawan di hotel Four Points By Sheraton Bali, Seminyak. Hal ini diperkuat oleh pendapat dari Chen.dkk (1998) dalam Novliadi (2008) yang dalam penelitiannya menyebutkan adanya hubungan terbalik antara OCB dengan turnover dimana karyawan yang memiliki OCB rendah cenderung akan meninggalkan organisasi dibandingkan dengan karyawan yang memiliki tingkat OCB yang tinggi.

Berdasarkan observasi pra penelitian yang dilakukan dari tanggal 3 Desember 2018 sampai 5 Juni 2019 di lingkungan hotel dan wawancara yang dilakukan dengan Ibu Kusuma Andayani selaku Human Resources Coordinator, dapat diketahui fakta terkait permasalahan Organizational Citizenship Behavior yang terjadi di Four Points By Sheraton Bali, Seminyak yang bisa dilihat pada Tabel 4

Tabel 4 Permasalahan Organizational Citizenship Behavior Karyawan Tetap dan Kontrak Four Points By Sheraton Bali, Seminyak.

\begin{tabular}{cllc}
\hline No & \multicolumn{1}{c}{ Indikator OCB } & \multicolumn{1}{c}{ Fakta OCB } & $\begin{array}{c}\text { Persentase Dari } \\
\text { Keseluruhan } \\
\text { Karyawan(\%) }\end{array}$ \\
\hline 1 & $\begin{array}{l}\text { Conscientiousness } \\
\text { (Kinerja yang melebihi } \\
\text { standar) }\end{array}$ & $\begin{array}{l}\text { Masih terdapat performa karyawan } \\
\text { yang dibawah standar dinilai oleh } \\
\text { atasan dan tamu. }\end{array}$ & $21 \%$ \\
\hline \multirow{2}{*}{$\begin{array}{l}\text { Civic Virtue (Partisipasi } \\
\text { Suk }\end{array}$} & $\begin{array}{l}\text { Karyawan enggan untuk ikut kegiatan } \\
\text { sosial dari perusahaan seperti bersih- } \\
\text { bersih lingkungan sekitar. }\end{array}$ & $23 \%$ \\
\hline
\end{tabular}




\begin{tabular}{llll}
\hline & & $\begin{array}{l}\text { Karyawan memiliki inisiatif rendah } \\
\text { untuk mencari informasi terkait } \\
\text { perkembangan organisasi. }\end{array}$ & $22 \%$ \\
\hline 3 & $\begin{array}{l}\text { Sportsmanship } \\
\text { (Kemampuan } \\
\text { mentoleransi situasi } \\
\text { tanpa keluhan) }\end{array}$ & $\begin{array}{l}\text { Karyawan mengeluh mengenai } \\
\text { lingkungan kerja. }\end{array}$ & $22 \%$ \\
\hline
\end{tabular}

Sumber : Hasil wawancara dengan pihak Human Resources Department, 2019

Berdasarkan Tabel 4 dapat diketahui bahwa permasalahan OCB yang tertinggi terletak pada indikator Civic Virtue yang menyatakan "23\% karyawan enggan untuk ikut kegiatan sosial dari perusahaan seperti bersih-bersih lingkungan sekitar", Berdasarkan wawancara awal dengan pihak Human Resources dapat diketahui bahwa beberapa karyawan lebih memilih untuk menggunakan waktu yang ada untuk menyelesaikan pekerjaan dibanding ikut kegiatan sosial. Sedangkan permasalahan OCB terendah terletak pada indikator Conscientiousness yang menyatakan bahwa "21\% masih terdapat performa karyawan yang dibawah standar dinilai oleh atasan dan tamu", performa yang dibawah standar ini umumnya terjadi pada periode dengan tingkat hunian yang tinggi, penyebab dari performa dibawah standar ini adalah ketidakmampuan karyawan dalam menangani beban kerja yang diberikan sehingga mengakibatkan hasil pekerjaan menjadi dibawah standar. Beberapa permasalahan Organizational Citizenship Behavior ini merupakan hal serius yang perlu diperhatikan perusahaan untuk mempertahankan dan meningkatkan performa perusahaan, adanya permasalahan terkait Organizational Citizenship Behavior akan menghambat produktifitas perusahaan dalam mencapai visi yang telah ditetapkan. Adapun standar persentase performa karyawan dalam Guest Voice Report seperti yang diungkapkan oleh Ibu Kusuma Andayani selaku Human Resources Coordinator bahwa:

Performa karyawan masih dinyatakan baik apabila berada di atas $80 \%$ dalam Guest Voice Report, permasalahan performa karyawan yang melebihi $20 \%$ dalam Guest Voice Report akan sangat berpengaruh negatif terhadap peringkat hotel (Kusuma Andayani, Wawancara, 6 Juli 2019).

Berdasarkan standar performa karyawan yang ditetapkan oleh hotel, dapat diartikan bahwa permasalahan terkait karyawan dianggap serius jika telah melebihi $20 \%$. Organ (1995) dalam Novliadi (2007) mengemukakan bahwa terdapat beberapa variabel yang dapat mempengaruhi OCB, dan salah satunya adalah dukungan organisasional (Perceived Organizational Support).

Rhoades dan Eisenberger (2002) dalam Azim (2016) menyebutkan bahwa Perceived Organizational Support adalah keinginan perusahaan untuk mendukung karyawan dengan mengapresiasi setiap kontribusi yang karyawan berikan serta peduli terhadap kehidupan kerja mereka, sebagai gantinya karyawan akan menunjukan perilaku positf yang memberikan keuntungan bagi perusahaan. Dukungan Organisasional dalam Perceived Organizational Support telah diterapkan oleh pihak Hotel Four Points By Sheraton Bali Seminyak sejak manajemen diambil alih oleh Marriott International tahun 2016. Berdasarkan wawancara yang dilakukan dengan Ibu Kusuma Andayani selaku Human Resources Coordinatior dapat diketahui bentukbentuk dukungan organisasional yang diterapkan oleh Hotel Four Points By Sheraton Bali Seminyak seperti yang terlihat pada Tabel 5 berikut : 
Tabel5 Bentuk Dukungan Perusahaan Ditinjau Dari Faktor POS

\begin{tabular}{|c|c|c|}
\hline No & Indikator POS & Dukungan Perusahaan \\
\hline 1 & Fairness (Keadilan) & $\begin{array}{l}\text { 1. Peraturan dan kebijakan yang adil untuk semua } \\
\text { golongan jabatan karyawan. } \\
\text { 2. Pemberian informasi terbaru terkait kebijakan } \\
\text { perusahaan lewat briefing, informasi tertulis, dan } \\
\text { Webinar } \\
\text { 3. Kepedulian perusahaan kepada semua karyawan } \\
\text { lewat pemberian tunjangan dan asuransi. } \\
\text { 4. Kesempatan memberikan pendapat terkait } \\
\text { kebijakan perusahaan. } \\
\text { 5. Menghargai martabat karyawan lewat dalam } \\
\text { pekerjaan lewat pemberian seragam yang sopan } \\
\text { dan perlakuan baik. }\end{array}$ \\
\hline 2. & $\begin{array}{l}\text { Supervisor Support } \\
\text { (Dukungan Atasan) }\end{array}$ & $\begin{array}{l}\text { 1. Bantuan atasan menyediakan prasarana pekerjaan } \\
\text { lewat Marriot Global Sources. } \\
\text { 2. Penilaian kinerja bawahan dari atasan. } \\
\text { 3. Pemberian instruksi yang baik dari atasan. } \\
\text { 4. Bantuan atasan dalam mencari solusi } \\
\text { permasalahan. } \\
\text { 5. Pemberian semangan dari atasan. }\end{array}$ \\
\hline 3 & $\begin{array}{l}\text { Organization Reward and } \\
\text { Job Condition } \\
\text { (Penghargaan dan Kondisi } \\
\text { Kerja) }\end{array}$ & $\begin{array}{l}\text { 1. Pemberian hadiah berupa voucher, piagam } \\
\text { penghargaan, dan peluang promosi untuk } \\
\text { karyawan terbaik per semester (Quarter) } \\
\text { 2. Gaji yang sesuai dengan tanggung jawab. } \\
\text { 3. Pemberian pelatihan berupa daily buzz, workshop, } \\
\text { dan Online Training pada karyawan. } \\
\text { 4. Pengaturan beban kerja untuk karyawan. } \\
\text { 5. Kesempatan karyawan menyelesaikan pekerjaan } \\
\text { secara mandiri. }\end{array}$ \\
\hline
\end{tabular}

Sumber : Hasil Wawancara (2019)

Berdasarkan Tabel 5 dapat diketahui bentuk dukungan organisasional hotel yang ditinjau dari dimensi Fairness (Keadilan), Supervisor Support (Dukungan Atasan), dan Organizaational Reward and Job Condition (Penghargaan Organisasi dan Kondisi Kerja). Dukungan organisasional dipercaya menjadi salah satu faktor yang dapat menciptakan sikap dimana karyawan di suatu perusahaan memberikan kontribusi yang lebih terhadap perusahaan dimana mereka bekerja yang disebut dengan Organizational Citizenship Behavior. Hal ini dimungkinkan karena dukungan organisasional memberi perhatian kepada karyawan dan ketika seorang karyawan senang dengan dukungan yang diberikan maka mereka ingin memberikan imbalan untuk mendukung organisasi tersebut (Eisenberger.dkk, 2001:43). Dukungan Organisasional (POS) yang telah diterapkan perusahaan menjadi faktor potensial yang bisa mempengaruhi Organizational Citizenship Behavior karyawan dikarenakan Perceived Organizational Support (POS) merupakan salah satu faktor penentu Organization Citizenship Behavior (OCB), dengan mengetahui pengaruh Perceived 
Organizational Support terhadap Organizational Citizenship Behavior maka perusahaan akan lebih terbantu untuk memilih tindakan yang lebih tepat dalam usaha menjaga dan meningkatkan performa karyawan. Berdasarkan latar belakang diatas maka penulis tertarik untuk meneliti mengenai "Pengaruh Perceived Organizational Support (POS) terhadap Organization Citizenship Behavior $(O C B)$ karyawan di Four Points By Sheraton Bali Seminyak"

\section{METODE PENELITIAN}

Penelitian dilakukan di hotel Four Points By Sheraton Bali Seminyak yang terletak di Jl.Cendrawasih 89D, Kuta Utara. Hotel ini merupakan hotel bintang empat yang memiliki 120 kamar. Pemilihan hotel Four Points By Sheraton Bali, Seminyak sebagai lokasi penelitian karena bredasarkan hasil observasi penelitian, diketahui bahwa karyawan atau staff di hotel ini masih memiliki permasalahan terkati Organizational Citizenship Behavior (OCB). Indikasi lain dari masih kurangnya OCB di hotel ini juga terlihat dari tingkat turnover yang berada diatas $10 \%$.

Devinisi Operasional Variabel yang digunakan dalam penelitian yaitu : Perceived Organizational Support (X) dan Organizational Citizenship Behavior (Y). Perceived Organizational Support adalah penilaian karyawan mengenai dukungan perusahaan serta kepedulian perusahaan terhadap kehidupan karyawan yang mempengaruhi perilaku produktif karyawan di perusahaan tersebut, adapun indikatornya yaitu : Fairness (Keadilan), Supervisor Support (Dukungan Atasan), serta Organization Reward and Job Condition (Penghargaan Organisasi dan Kondisi Kerja). Fairness (Keadilan). Organizational Citizenship Behavior adalah perilaku seseorang dalam organisasi untuk melakukan tindakan yang melebihi standar formal pekerjaannya, yang mana tindakan ini didasarkan atas kebebasan pribadi dan tidak terikat pada kewajibannya pada perusahaan. adapun indikatornya yaitu : Altruism (Kepedulian Sosial), Courtesy (Keramahan dan Rasa Hormat), Conscientiousness (Kinerja Melebihi Standar), Civic Virtue (Partisipasi Sukarela), dan Sportsmanship (Kemampuan Mentoleransi Keadaan). Adapun Definisi Operasional Variabel secara lengkap dapat dilihat pada Tabel 6

Tabel 6 Definisi Operasional Variabel

\begin{tabular}{|c|c|c|}
\hline Variabel & Indikator & Sub Indikator \\
\hline \multirow{12}{*}{$\begin{array}{l}\text { Perceived } \\
\text { Organizationa } \\
\text { l Support (X) } \\
\text { menurut } \\
\text { Rhoades dan } \\
\text { Eisenberg } \\
\text { (2002; dalam } \\
\text { Azim 2016) }\end{array}$} & \multirow{5}{*}{ Fairness (Keadilan) } & 1. Peraturan dan kebijakan yang adil untuk karyawan \\
\hline & & $\begin{array}{l}\text { 2. Pemberian informasi yang jelas terkait kebijakan } \\
\text { perusahaan lewat briefing, informasi tertulis, dan } \\
\text { Webinar }\end{array}$ \\
\hline & & $\begin{array}{l}\text { 3. Kesempatan memberikan pendapat terkait kebijakan } \\
\text { perusahaan. }\end{array}$ \\
\hline & & $\begin{array}{l}\text { 4. Kepedulian perusahaan terhadap seluruh golongan } \\
\text { karyawan tanpa membedakan jabatan. }\end{array}$ \\
\hline & & 5. Penghormatan martabat karyawan dalam pekerjaan. \\
\hline & \multirow{5}{*}{$\begin{array}{l}\text { Supervisor Support } \\
\text { (Dukungan Atasan) }\end{array}$} & 1. Pemberian semangat dari atasan. \\
\hline & & $\begin{array}{l}\text { 2. Bantuan atasan kepada karyawan untuk } \\
\text { mendapatkan sarana dan penunjang pekerjaan. }\end{array}$ \\
\hline & & Penilaian kinerja bawahan yang baik dari atasan. \\
\hline & & 4. Instruksi yang baik dari atasan \\
\hline & & $\begin{array}{l}\text { 5. Bantuan atasan mencari solusi permasalahaan dalam } \\
\text { pekerjaan }\end{array}$ \\
\hline & \multirow{2}{*}{$\begin{array}{l}\text { Organization } \\
\text { Reward and Job } \\
\text { Condition }\end{array}$} & 1. Gaji yang sesuai tanggung jawab. \\
\hline & & $\begin{array}{l}\text { 2. Penghargaan berupa piagam, voucher, dan peluang } \\
\text { promosi jabatan kepada karyawan. }\end{array}$ \\
\hline
\end{tabular}




\begin{tabular}{|c|c|c|}
\hline & $\begin{array}{l}\text { (Penghargaan dan } \\
\text { kondisi kerja) }\end{array}$ & $\begin{array}{l}\text { 3. Kesempatan karyawan untuk menyelesaikan } \\
\text { pekerjaan secara mandiri. }\end{array}$ \\
\hline & & $\begin{array}{l}\text { 4. Pemberian pelatihan kerja kepada karyawan berupa } \\
\text { online training, workshop dan daily buzz }\end{array}$ \\
\hline & & 5. Pengaturan beban kerja karyawan. \\
\hline & & 1. Membantu pekerjaan rekan yang tidak hadir \\
\hline & $\begin{array}{l}\text { Altruism } \\
\text { (Kepedulian Sosial) }\end{array}$ & $\begin{array}{l}\text { 2. Membantu rekan yang kesulitan dengan beban } \\
\text { kerjanya. }\end{array}$ \\
\hline & & 3. Membantu orientasi karyawan baru tanpa diminta \\
\hline & Courtesy & 1. Sikap hormat terhadap atasan \\
\hline & (Keramahan dan & 2. Sikap ramah dalam interaksi dengan karyawan lain \\
\hline & Rasa Hormat) & 3. Mencegah terjadinya konflik pekerjaan \\
\hline l Citizenship & Conscientiousness & $\begin{array}{l}\text { 1. Berusaha memberikan hasil pekerjaan melebihi } \\
\text { standar. }\end{array}$ \\
\hline $\begin{array}{l}\text { (OCB) } \\
\text { menurut }\end{array}$ & $\begin{array}{l}\text { (Kinerja Melebihi } \\
\text { Standar) }\end{array}$ & $\begin{array}{l}\text { 2. Bersedia mengambil kelebihan waktu (overtime) } \\
\text { untuk pekerjaan }\end{array}$ \\
\hline $\begin{array}{l}\text { Organ }(1988 \\
\text { dalam Zhang, }\end{array}$ & & $\begin{array}{l}\text { 3. Tidak menghabiskan waktu untuk kepentingan } \\
\text { pribadi. }\end{array}$ \\
\hline 2011) & Civic Virtue & $\begin{array}{l}\text { 1. Menghadiri kegiatan yang diadakan oleh organisasi } \\
\text { secara sukarela }\end{array}$ \\
\hline & $\begin{array}{l}\text { (Partisipasi } \\
\text { Sukarela) }\end{array}$ & $\begin{array}{l}\text { 2. Ikut terlibat dalam memberikan sumbangan ide } \\
\text { untuk kemajuan organisasi. }\end{array}$ \\
\hline & & $\begin{array}{l}\text { 3. } \begin{array}{l}\text { Bersedia meluangkan waktu untuk mencari } \\
\text { informasi terkait perkembangan organisasi. }\end{array} \\
\end{array}$ \\
\hline & Sportmanship & 1. Toleransi terhadap lingkungan kerja. \\
\hline & $\begin{array}{l}\text { (Kemampuan } \\
\text { Mentoleransi }\end{array}$ & $\begin{array}{l}\text { 2. Tidak mudah mengeluh terhadap pekerjaan yang } \\
\text { diberikan. }\end{array}$ \\
\hline & Keadaan) & $\begin{array}{l}\text { 3. Tidak membesar-besarkan permasalahan yang } \\
\text { terjadi. }\end{array}$ \\
\hline
\end{tabular}

Sumber : Rhoades dan Eisenberger (2002) dan Ogan (1988)

Data berdasarkan sumbernya dalam penelitian terdiri dari dua jenis yaitu : data primer dan sekunder. Jenis data dalam penelitian ini yaitu data kualitatif dan data kuantitatif. Teknik pengumpulan data yang digunakan dalam penelitian yaitu : observasi, wawancara, kusioner, studi pustaka dan dokumentasi. Populasi yang dijadikan sampel adalah karyawan tetap dan kontrak yang berjumlah 92 orang, General Manager dan 12 Head Of Department tidak dimasukan kedalam sampel sehingga jumlah sampel yang digunakan adalah 79 orang. Teknik analisis data yang digunakan yaitu : Analisis Skala Likert, Analisis Regresi Linear Sederhana, Uji T, Koefisien Korelasi, dan Koefisien Determinasi.

3. HASIL DAN PEMBAHASAN

1) Gambaran Umum Perceived Organizational Support Hotel Four Points By Sheraton Bali Seminyak.

Hotel Four Points By Sheraton Bali Seminyak memberikan beberapa dukungan organisasional kepada karyawan yang bekerja di perusahaan ini, dukungan ini telah diterapkan sejak tahun 2016 ketika manajemen hotel diambil alih oleh Marriott International. Dukungan ini ditujukan untuk meningkatkan kinerja karyawan dan juga untuk menunjang kenyamanan karyawan dalam bekerja sehingga diharapkankan mampu menghasilkan kinerja yang baik dalam kegiatan operasional perusahaan. Berdasarkan hasil wawancara dengan Ibu Kusuma Andayani selaku Human Resources Coordinator dapat diketahui bentuk dukungan organisasional yang 
diberikan oleh pihak Hotel Four Points By Sheraton Bali Seminyak kepada karyawannya terdiri dari tiga jenis yaitu : Keadilan (Fairness), Dukungan Atasan (Supervisor Support), serta Penghargaan dan Kondisi Kerja ( Organization Reward and Job Condition). Keadilan (Fairness) adalah cara perusahaan dalam memperlakukan karyawan secara adil, adapun penerapan indikator Fairness di Hotel Four Points By Sheraton Bali Seminyak meliputi : Peraturan yang adil untuk karyawan, pemberian informasi terbaru terkait kebijakan perusahaan, kesempatan karyawan berpendapat, kepedulian perusahaan terhadap seluruh golongan karyawan, dan penghargaan martabat karyawan. Dukungan keadilan ini menjadi tanggung jawab dari Human Resources Department yang mengatur pengelolaan setiap sumber daya manusia yang ada di dalam perusahaan, termasuk dalam menciptakan kebijakan yang adil terhadap karyawannya. Dukungan atasan (Supervisor Support) adalah peran atasan dalam membantu karyawan dalam pekerjaannya, dukungan atasan yang diterapkan di hotel ini meliputi : Bantuan atasan menyediakan sarana penunjang pekerjaan, pemberian semangat dari atasan, penilaian kinerja bawahan yang baik, instruksi kerja dari atasan, dan bimbingan atasan dalam mencari solusi permasalahan. General Manager dan masing-masing Head Of Department berperan dalam memberikan dukungan kepada bawahannya, dukungan ini akan dirasakan bawahan sebagai kepedulian atasan terhadap kesejahteraan mereka dalam bekerja. Penghargaan dan Kondisi Kerja (Organization Reward and Job Condition) adalah penghargaan perusahaan terhadap kinerja dari karyawan dan penyediaan kondisi kerja yang baik untuk karyawan, penerapan dukungan ini di hotel meliputi : gaji yang sesuai tanggung jawab, pemberian hadiah kepada karyawan terbaik, pemberian pelatihan kerja, pengaturan beban kerja karyawan, dan kesempatan karyawan menyelesaikan pekerjaan secara mandiri. Departemen Human Resources bertugas dalam menentukan penghargaan yang diberikan kepada karyawan terbaik, selain itu department ini juga memiliki tugas untuk meningkatkan kondisi kerja dari karyawan seperti dengan memberikan pelatihan untuk meningkatkan kemampuan karyawan dalam menyelesaikan pekerjaan.

\section{2) Gambaran Umum Organizational Citizenship Behavior Karyawan Di Hotel Four Points} By Sheraton Bali Seminyak

Organizational Citizenship Behavior adalah bentuk perilaku karyawan dalam memberikan kontribusi lebih kepada perusahaan. Berdasarkan hasil wawancara dengan Ibu Kusuma Andayani selaku Human Resources Coordinator dapat diketahui gambaran umum terkait prilaku Organizational Citizenship Behavior karyawan dalam indikator Altruism, Courtesy, Conscientiousness, Civic Virtue, dan Sportsmanship. Karyawan Hotel Four Points By Sheraton Bali Seminyak senantiasa memiliki sikap Altruism (Kepedulian Sosial) yang baik di tempat kerja, sikap ini meliputi : kesediaan menggantikan rekan kerja yang tidak hadir, membantu rekan dari departemen lain, dan membantu orientasi karyawan baru tanpa diminta. Karyaw an juga memiliki sikap ramah dan hormat (Courtesy) yang baik dalam lingkungan kerjanya, seperti : hormat kepada atasan, ramah dalam interaksi dengan karyawan lain, dan berusaha mencegah munculnya konflik dengan rekan kerja. Sikap kinerja melebihi standar (Conscientiousness) yang baik dari karyawan ditunjukan melalui kesediaan karyawan mengambil kelebihan waktu (overtime) untuk menyelesaikan pekerjaan dan tidak menghabiskan waktu untuk kepentingan pribadi, namun masih terdapat prilaku Conscientiousness karyawan yang kurang baik terkait penurunan kualitas pekerjaan dari karyawan. Prilaku Civic Virtue yang baik karyawan ditunjukan dengan adanya kesediaan karyawan dalam memberikan sumbangan ide dalam setiap kesempatan seperti Internal Meeting dan Associate General Meeting, namun masih terdapat prilaku Civic Virtue yang kurang baik dari karyawan terkait partisipasi karyawan yang kurang dalam kegiatan sosial dari organisasi dan inisiatif yang rendah dari karyawan untuk mencari informasi terbaru terkait perkembangan organisasi. Prilaku Sportsmanship (Kemampuan Mentoleransi Keadaan) yang baik dari karyawan ditunjukan dengan sikap karyawan yang tidak mengeluh terhadap pekerjaan yang diberikan dan tidak membesar-besarkan permasalahan yang terjadi di perusahaan, namun masih terdapat kekurangan dalam prilaku Sportsmanship karyawan terkait masih terdapanya keluhan karyawan terhadap kondisi lingkungan kerja yang kurang baik 


\section{3) Karakteristik Responden}

Karakteristik responden berdasarkan jenis kelamin dalam penelitian ini terdiri dari 51 orang responden laki-laki dan 28 orang responden perempuan. Karakteristik responden berdasarkan departemen yaitu : Departemen Housekeeping sejumlah 14 orang, Departemen Food and Beverage Kitchen sejumlah 13 orang, Departemen Food and Beverage Service sejumlah 11 orang, Departemen Front Office sejumlah 12 orang, Departemen Engineering sejumlah 9 orang, Departemen Accounting sejumlah 8 orang, Departemen Sales \& Marketing sejumlah 5 orang, Departemen Spa sejumlah 3 orang, Departemen Loss Prevention sejumlah 2 orang, Departemen Human Resources sejumlah 2 orang, Departemen Revenue sejumlah 1 orang, dan Departemen IT sejumlah 1 orang. Karakteristik responden berdasarkan usia yaitu : Usia 21-25 tahun sejumlah 19 orang, usia 26-30 tahun sejumlah 48 orang, usia 31-35 tahun sejumlah 7 orang, usia 36-40 tahun sejumlah 2 orang, dan usia lebih dari 40 tahun sejumlah 4 orang. Karakteristik responden berdasarkan latar belakang pendidikan yaitu : Pendidikan SMA/SMK sejumlah 21 orang, pendidikan D1 sejumlah 25 orang, pendidikan D2 sejumlah 2 orang, pendidikan D3 sejumlah 9 orang, pendidikan D4/S1 sejumlah 22 orang. Karakteristik responden berdasarkan status kepegawaian yaitu 52 responden adalah karyawan tetap dan 27 orang responden adalah karyawan kontrak. Karakteristik responden berdasarkan masa kerja yaitu : Masa kerja dibawah 2 tahun sejumlah 19 orang, masa kerja 3 tahun sejumlah 9 orang, masa kerja 3 tahun sejumlah 7 orang, masa kerja 4 tahun 12 orang, masa kerja 5 tahun sejumlah 15 orang, dan masa kerja diatas 5 tahun sejumlah 17 orang.

4) Uji Instrument Menggunakan Uji Validitas Dan Reliabilitas Tabel 7 Hasil Uji Va lidita s Instrumen

\begin{tabular}{llll}
\hline No & \multicolumn{1}{c}{ Variabel } & Rentang Alpha & Keterangan \\
\hline 1 & $\begin{array}{l}\text { Perceived Organizational } \\
\text { Support }(\mathrm{X})\end{array}$ & $0,630-0,643$ & Valid \\
& & & \\
\hline 2 & $\begin{array}{l}\text { Organizational Citizenship } \\
\text { Behavior }(\mathrm{Y})\end{array}$ & $0,334-0,755$ & Valid \\
\hline
\end{tabular}

Sumber : Hasil pengolahan data peneliti (2019)

Berdasarkan hasil uji validitas dapat diketahui bahwa seluruh item dalam instrument penelitian memiliki $r$ hitung lebih dari 0,30. Priyastama (2017: 168) menyatakan bahwa jika $r$ hasil positif dan $r$ hasil $>0,30$ maka item pertanyaan adalah valid.

Tabel 8 Hasil Uji Reliabilitas Instrumen

\begin{tabular}{llcl}
\hline No & \multicolumn{1}{c}{ Variabel } & Cronbach's Alpha & Keterangan \\
\hline 1 & $\begin{array}{l}\text { Perceived Organizational } \\
\text { Support }(\mathrm{X})\end{array}$ & 0,898 & Reliabel \\
\hline 2 & $\begin{array}{l}\text { Organizational Citizenship } \\
\text { Behavior }(\mathrm{Y})\end{array}$ & 0,860 & Reliabel \\
\hline
\end{tabular}

Sumber : Hasil pengolahan data peneliti (2019)

Berdasarkah hasil uji reliabilitas dapat diketahui bahwa nilai Cronbach's Alpha variabel POS dan OCB lebih tinggi dari 0,600. Priyastama (2017:169) menyatakan bahwa untuk menentukan apakah item dinyatakan reliabel dapat melihat batas nilai alpha 0,60 , item dengan reliabilitas dibawah 0,60 dinyatakan kurang baik dalam penelitian sehingga tidak dapat digunakan, dari pendapat ini dapat dinaytakan bahwa item variabel dinyatakan reliabel. 


\section{5) Uji Asumsi Klasik}

Tabel 9 Uji Normalitas

\begin{tabular}{|c|c|c|}
\hline & & $\begin{array}{c}\text { Unstandardized } \\
\text { Residual }\end{array}$ \\
\hline $\mathrm{N}$ & & 79 \\
\hline \multirow[t]{2}{*}{ Normal Parameters ${ }^{\mathrm{a}, \mathrm{b}}$} & Mean & .0000000 \\
\hline & Std. Deviation & 3.738333064 \\
\hline \multirow[t]{3}{*}{ Most Extreme Differences } & Absolute & .069 \\
\hline & Positive & .069 \\
\hline & Negative & -.042 \\
\hline Kolmogorov-Smirnov Z & & .615 \\
\hline Asymp. Siq. (2-tailed) & & .844 \\
\hline
\end{tabular}

Sumber : Hasil pengolahan data peneliti (2019)

Ghozali (2011) menyatakan bahwa kriteria yang digunakan dalam tes ini membandingkan antara tingkat signifikan yang didapat dalam tingkat alpha $(0,05)$ yang digunakan, dimana data tersebut dikatakan distribusi normal bila sig > alpha. Berdasarkah hasil uji normalitas dapat diketahui nilai Asymp Sig (2-tailed) sebesar 0,844 lebih tinggi dari taraf normalitas data sebesar 0,050 sehingga dapat disimpulkan bahwa data primer terdistribusi secara normal.

Tabel 10 Uji Heterokedastistas

\begin{tabular}{|c|c|c|c|c|c|c|}
\hline \multirow{2}{*}{\multicolumn{2}{|c|}{ Model }} & \multicolumn{2}{|c|}{$\begin{array}{l}\text { Unstandardized } \\
\text { Coefficients }\end{array}$} & \multirow{2}{*}{$\begin{array}{c}\begin{array}{c}\text { Standardized } \\
\text { Co efficients }\end{array} \\
\text { Beta }\end{array}$} & \multirow[b]{2}{*}{$\mathrm{t}$} & \multirow[b]{2}{*}{ Sig. } \\
\hline & & $B$ & Std. Error & & & \\
\hline \multirow[t]{2}{*}{1} & (Constant) & 6.237 & 2.546 & & 2.450 & .017 \\
\hline & $\begin{array}{l}\text { Perceived } \\
\text { Organizational Support }\end{array}$ & -.053 & .042 & -.142 & -1.256 & .213 \\
\hline
\end{tabular}

Sumber : Hasil pengolahan data penelitian (2019)

Supriyanto (2015) menyatakan bahwa jika tidak ada variabel bebas yang berpengaruh signifikan terhadap absolute residual atau nilai signifikansinya > 0,05 maka dapat disimpulkan tidak terjadi heteroskedastistas. Berdasarkan hasil uji heterokedastistas menggunakan metode Glejser dapat diketahui bahwa taraf signifikansi residual data primer sebesar 0,213 lebih besar dari taraf signifikansi uji Glejser sebesar 0,050 sehingga dapat disimpulkan bahwa data primer tidak memiliki heterokedastistas

Tabel 11 Uji Linearitas

\begin{tabular}{|c|c|c|c|c|c|c|c|}
\hline & & & $\begin{array}{l}\text { Sum of } \\
\text { Squares }\end{array}$ & $\mathrm{df}$ & Mean Square & $\mathrm{F}$ & Sig. \\
\hline \multirow{3}{*}{$\begin{array}{l}\mathrm{OC} \\
\mathrm{B}^{*} \\
\mathrm{PO} \\
\mathrm{S}\end{array}$} & \multirow{3}{*}{ Between Groups } & (Combined) & 1009.688 & 21 & 48.080 & 3.072 & .000 \\
\hline & & Linearity & 785.261 & 1 & 785.261 & 50.177 & .000 \\
\hline & & $\begin{array}{l}\text { Deviation from } \\
\text { Linearity }\end{array}$ & 224.427 & 20 & 11.221 & .717 & .792 \\
\hline & Within Groups & & 892.033 & 57 & 15.650 & & \\
\hline & Total & & 1901.722 & 78 & & & \\
\hline
\end{tabular}

Sumber : Hasil pengolahan data penelitian (2019)

Berdasarkan hasil uji linearitas dapat diketahui tingkat signifikansi Deviation from Linearity adalah 0,792 >0.05. Berdasarkan hasil ini dapat disimpulkan bahwa variabel POS memiliki hubungan linear dengan variabel OCB. 
6) Penilaian Karyawan Terhadap Perceived Organizational Support dan Organizational Citizenship Behavior.

Data primer berupa penilaian karyawan yang didapat dari kuesioner selanjutnya diberikan skor dan dianalisa sesuai dengan tabel skala likert dari Abdullah (2015). Adapun variabel yang dinilai oleh karyawan lewat kuesioner yaitu : Percieved Organizational Support dan Organizational Citizenship Behavior. Hasil penilaian karyawan mengenai Percieved Organizational Support dan Organizational Citizenship Behavior di Hotel Four Points By Sheraton Bali Seminyak akan dijelaskan sebagai berikut. :

Tabel 12 Penilaian Karyawan Mengenai Percieved Organizational Support

\begin{tabular}{|c|c|c|c|c|c|c|c|c|c|}
\hline \multirow{2}{*}{$\begin{array}{l}\mathbf{N} \\
\mathbf{0}\end{array}$} & \multirow{2}{*}{ Indikator } & \multicolumn{5}{|c|}{ Jawaban } & \multirow{2}{*}{$\begin{array}{l}\text { Total } \\
\text { Skor }\end{array}$} & \multirow{2}{*}{$\begin{array}{c}\text { Rata- } \\
\text { rata }\end{array}$} & \multirow{2}{*}{ Ket. } \\
\hline & & STS & TS & $\mathbf{N}$ & $\mathbf{S}$ & $\mathbf{S S}$ & & & \\
\hline \multicolumn{10}{|c|}{ Fairness (Keadilan) } \\
\hline 1 & $\begin{array}{l}\text { Penghormatan martabat } \\
\text { karyawan dalampekerjaan. }\end{array}$ & 0 & 0 & 5 & 43 & 31 & 342 & 4.33 & $\begin{array}{l}\text { Sangat } \\
\text { Baik }\end{array}$ \\
\hline 2 & $\begin{array}{l}\text { Pemberian informasi yang jelas } \\
\text { terkait kebijakan perusahaan } \\
\text { lewat briefing, informasi } \\
\text { tertulis, dan Webinar }\end{array}$ & 0 & 0 & 6 & 46 & 27 & 337 & 4.27 & $\begin{array}{l}\text { Sangat } \\
\text { Baik }\end{array}$ \\
\hline 3 & $\begin{array}{l}\text { Kepedulian perusahaan } \\
\text { terhadap seluruh golongan } \\
\text { karyawan tanpa membedakan } \\
\text { jabatan lewatpemberian } \\
\text { tunjangan dan asuransi }\end{array}$ & 0 & 0 & 9 & 42 & 28 & 335 & 4.24 & $\begin{array}{l}\text { Sangat } \\
\text { Baik }\end{array}$ \\
\hline 4 & $\begin{array}{l}\text { Peraturan dan kebijakan yang } \\
\text { adil untuk karyawan }\end{array}$ & 0 & 0 & 7 & 50 & 22 & 331 & 4.19 & Baik \\
\hline 5 & $\begin{array}{l}\text { Kesempatan memberikan } \\
\text { pendapat terkait kebijakan } \\
\text { perusa haan. }\end{array}$ & 0 & 0 & 10 & 57 & 12 & 318 & 4.03 & Baik \\
\hline \multicolumn{7}{|c|}{ TotalSkorIndikator } & \multicolumn{3}{|c|}{1663} \\
\hline \multicolumn{7}{|c|}{ Rata-rata Indikator } & \multicolumn{3}{|c|}{4,21} \\
\hline & Penilaian Ind & ator & & & & & & Sanga & \\
\hline
\end{tabular}

\begin{tabular}{llllllllll}
\hline Supervisor Support (Dukungan Atasan) & & & & & & & \\
\hline 1 & Instruksi ya ng baik dari atasan & 0 & 0 & 7 & 47 & 25 & 334 & 4.23 & $\begin{array}{c}\text { Sangat } \\
\text { Baik }\end{array}$ \\
\hline & $\begin{array}{l}\text { Bantuan atasan kepada } \\
\text { karyawan untuk mendapatkan } \\
\text { sarana dan penunjang } \\
\text { pekerjaan. }\end{array}$ & 0 & 0 & 8 & 52 & 19 & 327 & 4.14 & Baik \\
\hline 3 & $\begin{array}{l}\text { Pemberian semangat dari } \\
\text { ata san. }\end{array}$ & 0 & 0 & 16 & 41 & 22 & 322 & 4.08 & Baik \\
\hline 4 & $\begin{array}{l}\text { Penilaian kinerja bawahan yang } \\
\text { baik dari atasan. }\end{array}$ & 0 & 0 & 15 & 51 & 13 & 314 & 3.97 & Baik \\
\hline 5 & $\begin{array}{l}\text { Bantuan atasanmencarisolusi } \\
2\end{array}$ & 0 & 0 & 16 & 54 & 9 & 309 & 3.91 & Baik \\
\hline
\end{tabular}


permasalahaan dalam pekerjaan

\begin{tabular}{|c|c|c|c|c|c|c|c|c|c|}
\hline \multicolumn{7}{|c|}{ TotalSkor Indikator } & \multicolumn{3}{|c|}{1297} \\
\hline \multicolumn{7}{|c|}{ Rata-rata Indikator } & \multicolumn{3}{|c|}{4,07} \\
\hline \multicolumn{7}{|c|}{ Penilaian Indikator } & \multicolumn{3}{|c|}{ Baik } \\
\hline \multicolumn{10}{|c|}{ Organization RewardandJob Condition (Penghargaan dan Kondisi Kerja) } \\
\hline 1 & $\begin{array}{l}\text { Kesempatan karyawan untuk } \\
\text { menyelesaikan pekerjaan secara } \\
\text { mandiri. }\end{array}$ & 0 & 0 & 7 & 57 & 15 & 324 & 4.12 & Baik \\
\hline 2 & $\begin{array}{l}\text { Penghargaan berupa piagam, } \\
\text { voucher, dan peluang promosi } \\
\text { jabatan kepada karyawan } \\
\text { berprestasi. }\end{array}$ & 0 & 0 & 17 & 37 & 25 & 324 & 4.10 & Baik \\
\hline 3 & $\begin{array}{l}\text { Pemberian pelatihan kerja } \\
\text { kepa da karyawan berupa online } \\
\text { training dan daily buzz }\end{array}$ & 0 & 0 & 5 & 63 & 11 & 322 & 4.08 & Baik \\
\hline 4 & $\begin{array}{l}\text { Pengaturan beban kerja } \\
\text { karyawan. }\end{array}$ & 0 & 11 & 21 & 43 & 4 & 277 & 3.51 & Baik \\
\hline 5 & $\begin{array}{l}\text { Gaji yang sesuaitanggung } \\
\text { jawab. }\end{array}$ & 0 & 8 & 31 & 38 & 2 & 271 & 3.43 & Baik \\
\hline \multicolumn{7}{|c|}{ TotalSkor Indikator } & \multicolumn{3}{|c|}{1518} \\
\hline \multicolumn{7}{|c|}{ Rata-rata Indikator } & \multicolumn{3}{|c|}{3,85} \\
\hline \multicolumn{7}{|c|}{ Penilaian Indikator } & \multicolumn{3}{|c|}{ Baik } \\
\hline
\end{tabular}

Sumber : Hasil pengolahan data penelitian (2019)

Berdasarkan Tabel 12 dapat diketahui indikator Fairness dinilai sangat baik oleh karyawan, sedangkan indikator Supervisor Support dan Organization Reward and Job Conditiion dinilai baik oleh karyawan. Adapun indikator yang mendapat penilaian paling tinggi adalah indikator Fairness (Keadilan) dengan rata-rata skor 4,21, sebagian besar karyawan tetap dan kontrak merasa bahwa peraturan dan kebijakan prosedural perusahaan sudah adil sehingga tidak ada ketimpangan antara satu karyawan dengan yang lainnya, hasil analisa ini diperkuat oleh teori Shore and Shore (1995) dalam Eisenberger (2002) yang menyatakan bahwa keadilan kepada karyawan dalam kebijakan perusahaan memiliki efek kumulatif yang kuat terhadap persepsi karyawan terhadap dukungan perusahaan. Sedangkan indikator yang mendapat penilaian terendah adalah indikator Organization Reward and Job Condition (Penghargaan dan Kondisi Kerja) dengan rata-rata nilai 3,85, meskipun sebagian besar karyawan merasa kondisi kerja yang diberikan perusahaan sudah baik, namun sebagian kecil karyawan masih merasa bahwa gaji dan beban kerja yang diberikan perusahaan masih belum cukup baik dan perlu ditingkatkan. Shore and Shore (1995) dalam Eisenberger (2002) dalam hasil penelitiannya mengatakan bahwa penghargaan perusahaan dan kondisi kerja memiliki kaitan yang erat dengan POS, meliputi : pembayaran, promosi, kemandirian, peran stressor, dan pelatihan kerja. 
Tabel 13 Penilaian Karyawan Terhadap Organizational Citizenship Behavior

\begin{tabular}{|c|c|c|c|c|c|c|c|c|c|}
\hline \multirow{2}{*}{$\begin{array}{l}\mathbf{N} \\
\mathbf{o}\end{array}$} & \multirow{2}{*}{ Indikator } & \multicolumn{5}{|c|}{ Jawaban } & \multirow{2}{*}{$\begin{array}{c}\text { Tota } \\
\text { I } \\
\text { Skor }\end{array}$} & \multirow{2}{*}{$\begin{array}{l}\text { Rata- } \\
\text { rata }\end{array}$} & \multirow{2}{*}{ Ket. } \\
\hline & & STS & TS & $\mathbf{N}$ & $\mathbf{S}$ & SS & & & \\
\hline \multicolumn{10}{|c|}{ Courtesy (Keramahan dan Rasa Hormat) } \\
\hline 1 & Sikap hormat terhadap a tasan & 0 & 0 & 0 & 32 & 47 & 405 & 4.59 & SangatBaik \\
\hline 2 & $\begin{array}{l}\text { Mencegah terjadinya konflik } \\
\text { dengan rekan kerja. }\end{array}$ & 0 & 0 & 4 & 29 & 46 & 417 & 4.53 & SangatBaik \\
\hline 3 & $\begin{array}{l}\text { Sikap ra mah dalam interaksi } \\
\text { dengan karyawan la in }\end{array}$ & 0 & 0 & 0 & 43 & 36 & 388 & 4.46 & SangatBaik \\
\hline \multicolumn{7}{|c|}{ Total Skor Indikator } & \multicolumn{3}{|c|}{1210} \\
\hline \multicolumn{7}{|c|}{ Rata-rata Indikator } & \multicolumn{3}{|c|}{4,53} \\
\hline \multicolumn{7}{|c|}{ Penila ian Indikator } & \multicolumn{3}{|c|}{ SangatBaik } \\
\hline
\end{tabular}

\section{Altruism (Kepedulian Sosial)}

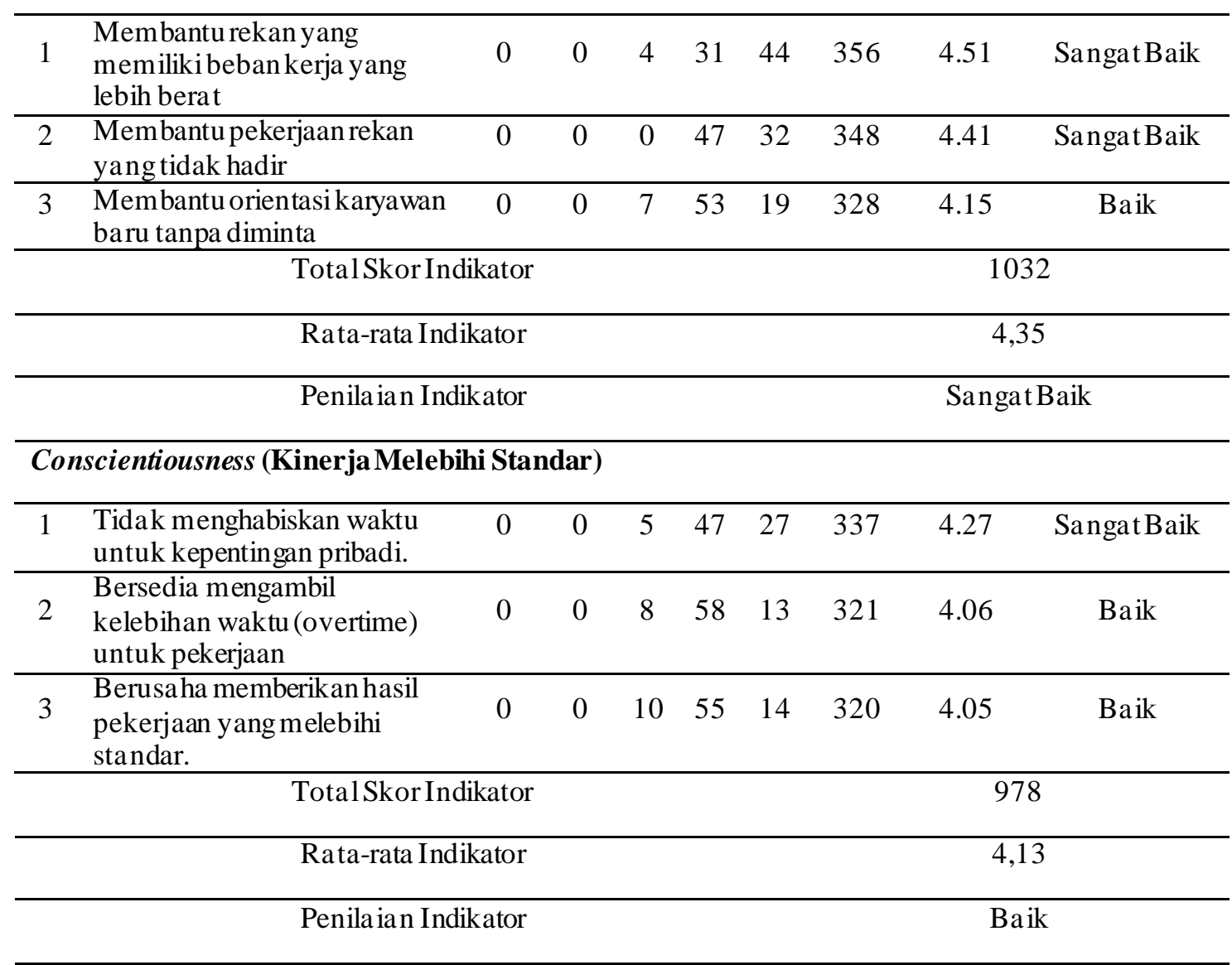

\begin{tabular}{lllllllllll}
\hline Sportmanship (Kemampuan Mentoleransi Keadaan) & & & & & \\
\hline 1 & $\begin{array}{l}\text { Tidak membesar-besarkan } \\
\text { permasalahan yang terjadi. }\end{array}$ & 0 & 0 & 4 & 57 & 18 & 330 & 4.18 & Baik \\
\hline 2 & $\begin{array}{l}\text { Tidak mudahmengeluh } \\
\text { terha dap pekerjaan yang } \\
\text { diberikan. }\end{array}$ & 0 & 0 & 7 & 54 & 18 & 327 & 4.14 & Baik \\
\hline 3 & $\begin{array}{l}\text { Toleransiterhadap lingkungan } \\
\text { kerja. }\end{array}$ & 0 & 0 & 13 & 48 & 17 & 316 & 4.00 & Baik \\
\hline \multicolumn{2}{c}{ TotalSkor Indikator } & & & & & 977 & \\
\hline
\end{tabular}




\begin{tabular}{|c|c|c|c|c|c|c|c|c|c|}
\hline & \multicolumn{6}{|c|}{ Rata-rata Indikator } & \multicolumn{3}{|c|}{4,12} \\
\hline & \multicolumn{6}{|c|}{ Penila ian Indikator } & \multicolumn{3}{|c|}{ Baik } \\
\hline \multicolumn{10}{|c|}{ Civic Virtue (Partisipasi Sukarela) } \\
\hline 1 & $\begin{array}{l}\text { Memberikan sumbangan ide } \\
\text { untuk kemajuan organisasi }\end{array}$ & 0 & 0 & 8 & 55 & 16 & 324 & 4.10 & Baik \\
\hline 2 & $\begin{array}{l}\text { Menghadiri kegia tan sosial } \\
\text { yang dia dakan oleh organisasi } \\
\text { secara sukarela }\end{array}$ & 0 & 5 & 9 & 45 & 20 & 317 & 4.01 & Baik \\
\hline 3 & $\begin{array}{l}\text { Bersedia meluangkan waktu } \\
\text { untuk mencari informasi } \\
\text { terkait perkembangan } \\
\text { organisasi }\end{array}$ & 0 & 0 & 12 & 57 & 10 & 314 & 3.97 & Baik \\
\hline \multicolumn{7}{|c|}{ TotalSkor Indikator } & \multicolumn{3}{|c|}{955} \\
\hline \multicolumn{7}{|c|}{ Rata-rata Indikator } & \multicolumn{3}{|c|}{4,03} \\
\hline \multicolumn{7}{|c|}{ Penila ian Indikator } & \multicolumn{3}{|c|}{ Baik } \\
\hline
\end{tabular}

Sumber : Hasil pengolahan data peneliti (2019)

Berdasarkan Tabel 13 dapat diketahui dua indikator variabel Organizational Citizenship Behavior yaitu Altruism dan Courtesy mendapat penilaian sangat baik dari karyawan, sedangkan tiga indikator lainnya yaitu : Concientiousness, Civic Virtue, dan Sportsmanship mendapat penilaian baik dari karyawan. Indikator yang mendapat peniliaian tertinggi adalah indikator Courtesy (Keramahan dan rasa hormat) dengan rata-rata skor 4,53, karyawan hotel Four Points By Sheraton Bali Seminyak senantiasa menghormati atasannya di perusahaan serta bersikap ramah terhadap sesama karyawan, contohnya seperti bersikap sopan terhadap atasan dalam pekerjaan dan sikap ramah saat bersosialisasi dengan karyawan lain saat jam istirahat. Podaskoff (2000) dalam Tambe dan Shanker (2014) menyatakan bahwa karyawan yang menunjukan prilaku keramahan akan mencegah potensi konflik dalam kelompok sehingga mengurangi waktu yang dibutuhkan untuk manajemen konflik. Indikator yang mendapat penilaian paling rendah adalah Civic Virtue dengan rata-rata skor 4,03, sebagian kecil karyawan kurang setuju untuk meluangkan waktunya dalam mengikuti kegiatan sosial dari perusahaan, karyawan berpendapat bahwa akan lebih baik jika waktu yang ada digunakan untuk menyelesaikan pekerjaan, khususnya jika terdapat pekerjaan yang bersifat mendesak. Wawancara lebih lanjut dengan 12 Head Of Department dilakukan untuk mengkonfirmasi jawaban OCB dari karyawan, adapun hasil wawancara dengan 12 Head Of Department menyatakan bahwa sebagian besar pernyataan OCB karyawan sudah sesuai dengan pernyataan dari Head Of Department yang menyatakan sebagian besar prilaku OCB karyawan Hotel Four Points By Sheraton Bali Seminyak sudah baik. Meski demikian, terdapat empat pernyataan OCB karyawan dalam tiga indikator yaitu : Conscientiousness, Civic Virtue, dan Sportsmanship yang dinilai kontradiktif dengan pernyataan dari 12 Head Of Department. Indikator Conscientiousness karyawan terkait berusaha memberikan hasil pekerjaan yang melebihi standar dinilai masih kurang oleh masing-masing Head Of Department, meskipun sebagian besar karyawan menyatakan selalu berusaha memberikan hasil pekerjaan diatas standar, masih terdapat ketidakmampuan beberapa karyawan dalam mempertahankan kualitas pekerjaan ketika kuantitas pekerjaan bertambah yang menyebabkan performa karyawan di Guest Voice Report berada di bawah 80\%, seperti yang terjadi di bulan Januari 2019. Indikator Civic Virtue pada pernyataan "Menghadiri kegiatan sosial yang diadakan oleh organisasi secara sukarela" dan "Bersedia meluangkan waktu untuk mencari informasi terkait perkembangan organisasi" dinilai masih kurang oleh masing-masing Head Of Department, meskipun sebagian besar karyawan menyatakan bersedia untuk menghadiri kegiatan sosial organisasi secara sukarela dan meluangkan waktu untuk mencari informasi terkait perkembangan organisasi, 
kesibukan karyawan dalam bekerja membuat karyawan enggan dalam meluangkan waktu untuk mencari informasi terkait perkebangan organisasi dan mengikuti kegiatan sosial yang diadakan oleh organisasi, kebanyakan kegiatan sosial dari organisasi seperti bersih-bersih lingkungan sekitar lebih banyak dihadiri oleh karyawan magang dibandingkan karyawan tetap dan kontrak. Indikator Sportsmanship karyawan dalam pernyataan "Toleransi terhadap lingkungan kerja" dinilai masih kurang oleh sebagian besar Head Of Department, meskipun sebagian besar karyawan menyatakan memiliki toleransi yang baik terhadap lingkungan kerja yang kurang baik, kondisi lingkungan kerja yang kurang baik secara terus-menerus menyebabkan munculnya keluhan karyawan terhadap perusahaan, seperti misalnya munculnya keluhan karyawan ketika pendingin ruangan di ruang Sales \& Marketing yang sering mati beberapa kali dalam satu minggu..

7) Analisis Regresi Linear Sederhana

Tabel 14 Hasil Analisa Regresi Linear Sederhana dan Uji T

\begin{tabular}{|c|c|c|c|c|c|c|}
\hline \multirow{2}{*}{\multicolumn{2}{|c|}{ Model }} & \multicolumn{2}{|c|}{$\begin{array}{c}\text { Unstandardized } \\
\text { Coefficients } \\
\end{array}$} & \multirow{2}{*}{$\begin{array}{c}\begin{array}{c}\text { Standardized } \\
\text { Coefficients }\end{array} \\
\text { Beta }\end{array}$} & \multirow[b]{2}{*}{$\mathrm{T}$} & \multirow[b]{2}{*}{ Sig. } \\
\hline & & $\mathrm{B}$ & Std. Error & & & \\
\hline 1 & (Constant) & 31.142 & 4.415 & & 7.054 & .000 \\
\hline & $\begin{array}{l}\text { Perceived Organizational } \\
\text { Support }\end{array}$ & .534 & .073 & .643 & 7.359 & .000 \\
\hline
\end{tabular}

Sumber : Hasil pengolahan data penelitian (2019)

Berdasarkan hasil analisa Regresi Linear Sederhana pada Tabel 17 dapat diketahui model regresi yang terbentuk yaitu :

$\mathrm{Y}=\mathrm{a}+\mathrm{bX}$

$\mathrm{Y}=31,142+0,534 \mathrm{X}$.

Persamaan Regresi Linear Sederhana diatas dapat dijelaskan sebagai berikut :

Konstanta (a)

Nilai konstanta dari Regresi Linear Sederhana adalah 31.142, berdasarkan nilai konstanta dapat disimpulkan jika tidak terdapat Perceived Organizational Support (X) maka nilai konsisten Organizational Citizenship Behavior (Y) karyawan adalah sebesar 31,142.

\section{Perceived Organizational Support (X)}

Koefisien regresi dari Perceived Organizational Support (X) adalah 0,534. Berdasarkan hasil koefisien regresi dapat diketahui bahwa setiap penambahan $1 \%$ tingkat Percieved Organizational Support (X) maka tingkat Organizational Citizenship Behavior (Y) karyaw an akan bertambah sebesar 0,534. Berdasarkan hasil ini dapat diartikan bahwa setiap peningkatan dari Perceived Organizational Support akan mempengaruhi peningkatan dari prilaku Organizational Citizenship Karyawan. Perceived Organizational Support dari perusahaan dirasakan karyawan sebagai bentuk kepedulian perusahaan terhadap mereka dan hal ini mampu mendorong timbulnya prilaku dalam memberikan kontribusi lebih dari karyawan kepada perusahaan. Salah satu dukungan yang paling baik dirasakan oleh karyawan adalah terkait keadilan perusahaan (Fairness), hal ini medorong perilaku OCB yang sangat baik dari karyawan terkait keramahan dan rasa hormat mereka (Courtesy) dan kepedulian mereka terhadap sesama karyawan (Altruism). 


\section{8) Analisa Hipotesis Menggunakan Kurva Uji T}

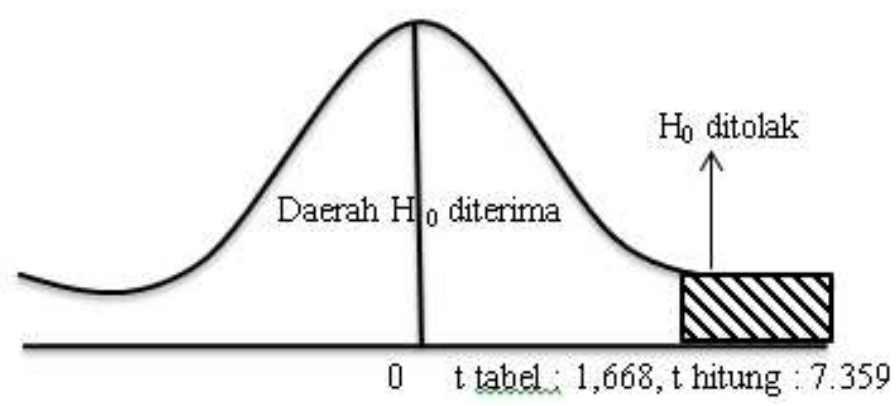

Gambar 1. Hasil Analisa Hipotesis Dengan Kurva Uji T

Berdasarkan Tabel 14 dapat diketahui bahwa nilai t hitung pengaruh variabel POS terhadap OCB adalah 7,359 dengan taraf toleransi signifikansi 0,000. Analisa Uji T menggunakan kurva Uji T dapat diketahui nilai t hitung sebesar 7.359 memiliki arah positif dan lebih besar dari nilai t tabel yaitu 1,666, tingkat signifikansi t hitung sebesar 0,000 lebih kecil dari taraf toleransi kesalahan 0,05 sehingga dapat dinyatakan variabel POS berpengaruh signifikan terhadap variabel OCB. Berdasarkan dari hasil analisa maka keputusan uji hipotesis yang diambil adalah penolakan $\mathrm{H}_{0}$ dan Penerimaan $\mathrm{Ha}$. Sehingga dapat disimpulkan bahwa terdapat pengaruh positf dan signifikan variabel Perceived Organizational Support terhadap Organizational Citizenship Behavior karyawan di Hotel Four Points By Sheraton Bali Seminyak Dukungan keadilan (Fairness) perusahaan seperti penghormatan martabat karyawan dalam bekerja, kepedulian perusahaan kepada semua golongan jabatan lewat pemberian asuransi dan tunjangan, serta pemberian informasi terkait kebijakan perusahaan dinilai karyawan sebagai bentuk perhatian perusahaan terhadap mereka. Dukungan atasan (Supervisor Support) seperti Instruksi yang baik dari atasan dalam pekerjaan, bantuan atasan menyediakan sarana penunjang pekerjaan, dan pemberian semangat atasan membuat karyawan merasa mendapat kepedulian yang baik dari atasannya. Dukungan penghargaan dan kondisi kerja (Organization Reward and Job Condition) yang diberikan oleh perusahaan seperti kesempatan menyelesaikan pekerjaan secara mandiri, penghargaan berupa piagam, voucher, dan peluang promosi, serta pemberian pelatihan kerja memberikan memberikan gambaran bahwa perusahaan menghargai hasil kinerja baik mereka dan peduli terhadap kondisi kerja karyawan. Adanya dukungan organisasional ini berpengaruh positif terhadap keinginan karyawan untuk membalas kebaikan yang telah diberikan perusahaan lewat kontribusi lebih mereka di dalam pekerjaannya atau yang dikenal dengan sebutan OCB (Organizational Citizenship Behavior), adapun beberapa prilaku OCB karyawan Four Points By Sheraton Bali Seminyak seperti : Kesediaan menggantikan rekan kerja yang tidak hadir, membantu rekan kerja yang kesulitan, keramahan dalam interaksi dengan karyawan lain, rasa hormat kepada atasan, ikut serta menyumbangkan ide untuk kemajuan organisasi, tidak membesar-besarkan permasalahan di dalam organisasi, dan tidak menghabiskan waktu kerja untuk kepentingan pribadi. 


\section{9) Koefisien Korelasi}

Tabel 15 Hasil Analisa Koefisien Korelasi dan Koefisien Determinasi

\begin{tabular}{ccccc}
\hline Model & $\mathrm{R}$ & R Square & $\begin{array}{c}\text { Adjusted R } \\
\text { Square }\end{array}$ & $\begin{array}{c}\text { Std. Error of the } \\
\text { Estimate }\end{array}$ \\
\hline 1 & $.643^{\mathrm{a}}$ & .413 & .405 & 3.80782 \\
\hline
\end{tabular}

Sumber : Hasil pengolahan data penelitian (2019)

Trijono (2015) menjelaskan bahwa korelasi merupakan pengukur hubungan dua variabel atau lebih yang dinyatakan dengan derajat keeratan atau tingkat hubungan antar variabel-variabel. Berdasarkan Tabel 15 dapat diketahui koefisien korelasi (R) adalah 0,643, koefisien korelasi ini memiliki arah positif dan termasuk ke dalam kategori korelasi kuat karena berada pada rentang 0,600-0,799. Hasil analisa ini menunjukan bahwa variabel Percieved Organizational Support memiliki pengaruh yang kuat serta positif terhadap variabel Organizational Citizenship Behavior karyawan di Hotel Four Points By Sheraton Bali Seminyak. Dukungan organisasional (POS) yang telah diterapkan perusahaan sejak tahun 2016 memberikan pengaruh yang kuat terhadap keinginan karyawan dalam memberikan kontribusi lebih terhadap perusahaan (OCB). Dukungan atasan (Supervisor Support) seperti instruksi yang baik dari atasan dan bantuan atasan dalam pengadaan sarana pekerjaan dinilai sudah baik, penilaian yang sama baik juga diberikan pada indikator Penghargaan dan Kondisi Kerja (Organization Reward and Job Condition) seperti kesempatan menyelesaikan tugas secara mandiri dan penghargaan berupa piagam dan hadiah. Faktor dominan dari dukungan organisasional yang dirasakan karyawan paling baik adalah Dukungan Keadilan (Fairness) seperti : penghormatan martabat karyawan dalam bekerja, kepedulian perusahaan kepada semua golongan jabatan lewat pemberian asuransi dan tunjangan, pemberian informasi terkait kebijakan perusahaan, serta peraturan dan kebijakan yang adil untuk karyawan. Dukungan organisasional ini dinilai sebagai bentuk kepedulian perusahaan terhadap kesejahteraan mereka sehingga berpengaruh kuat terhadap keinginan karyawan untuk memberikan timbal balik yang positif terhadap perusahaan melalui prilaku OCB, beberapa perilaku OCB paling baik yang ditunjukan karyawan seperti kepedulian mereka terhadap rekan kerja (Altruism) serta sikap ramah dan hormat karyawan (Courtesy) terhadap karyawan lain dan atasan.

10) Koefisien Determinasi

Tabel 16 Hasil Analisa Koefisien Determinasi

\begin{tabular}{ccccc}
\hline Model & $\mathrm{R}$ & R Square & $\begin{array}{c}\text { Adjusted R } \\
\text { Square }\end{array}$ & $\begin{array}{c}\text { Std. Error of the } \\
\text { Estimate }\end{array}$ \\
\hline 1 & $.643^{\mathrm{a}}$ & .413 & .405 & 3.80782 \\
\hline
\end{tabular}

Sumber : Hasil pengolahan data penelitian (2019)

Koefisien Determinasi adalah tingkatan seberapa besar variabel bebas mempengaruhi variabel terikat. Berdasarkan Tabel 4.16 dapat diketahui koefisien determinasi (Adjusted $R$ Square) adalah 0,405, angka ini kemudian dikalikan $100 \%$ sehingga didapat hasil 40,5\%. Berdasarkan nilai ini dapat disimpulkan bahwa variabel Percieved Organizational Support (X) mempengaruhi variabel Organizational Citizenship Behavior (Y) sebesar 40,5\%, dan sisan ya $59,5 \%$ dipengaruhi oleh faktor lain yang tidak dibahas dalam penelitian ini seperti : Budaya dan iklim organisasi, kepribadian dan suasana hati, persepsi terhadap kualitas interaksi atasan bawahan, masa kerja, dan jenis kelamin. Percieved Organizational Support yang telah diimplementasikan perusahaan mampu mempengaruhi 40,5 \% dari sikap Organizational Citizenship Behavior karyawan Hotel Four Points By Sheraton Bali Seminyak. Keadilan 
organisasi yang diberikan perusahaan (Fairness), dukungan atasan (Supervisor Support), serta Penghargaan dan Kondisi Kerja (Organization Reward and Job Condition) dari perusahaan menjadi salah satu faktor yang menyebabkan karyawan merasa senang ketika bekerja sehingga mampu untuk mempengaruhi prilaku OCB mereka di dalam organisasi, meliputi : Kepedulian karyawan terhadap rekan kerja (Altruism), Keramahan dan rasa hormat karyawan (Courtesy), Keinginan karyawan untuk bekerja lebih (Conscientiousness), Partisipasi sukarela karyawan (Civic Virtue), dan Sikap toleransi karyawan terhadap kondisi pekerjaan (Sportsmanship).

\section{KESIMPULAN}

Berdasarkan pembahasan yang telah diuraikan sebelumnya dapat ditarik kesimpulan bahwa POS memiliki pengaruh yang positif dan signifikan terhadap OCB karyawan di Hotel Four Points By Sheraton Bali Seminyak. Hasil persamaan regresi pengaruh POS terhadap OCB adalah Y $=31,142$ $+0,534 \mathrm{X}$, artinya adalah jika tidak terdapat variabel POS maka OCB karyawan secara konstan adalah 31,142 dan setiap pertambahan 1\% variabel POS maka OCB karyawan akan meningkat sebesar 0,534. Hasil uji hipotesis menggunakan Uji T menunjukan bahwa variabel POS memiliki pengaruh yang positif dan signifikan terhadap variabel OCB dengan nilai t hitung 7,359 dan taraf signifikansi 0,000, POS dinilai karyawan sebagai bentuk kepedulian perusahaan terhadap mereka sehingga mendorong timbal balik yang baik dari karyawan lewat prilaku OCB. Variabel POS memiliki pengaruh yang kuat terhadap OCB dengan koefisien korelasi 0,643, hasil ini menunjukan bahwa POS memiliki pengaruh yang kuat terhadap peningkatan sikap OCB karyawan. Analisa koefisien deteriminasi pengaruh variabel POS terhadap OCB di Hotel Four Points By Sheraton Bali seminyak menunjukan hasil 0,405 yang artinya adalah variabel POS memiliki pengaruh sebesar 40,5\% terhadap variabel OCB karyawan. Hasil ini memberikan gambaran bahwa POS yang telah diimplementasikan perusahaan memiliki pengaruh yang potensial terhadap prilaku OCB karyawan, hal ini dimungkinkan karena POS telah dianggap karyawan sebagai salah satu faktor yang membuat mereka senang dan memotivasi mereka dalam memberikan kontribusi lebih untuk perusahaan

\section{Ucapan terima kasih}

Penulis mengucapkan terimakasih kepada dosen pembimbing yang senantiasa memberikan bimbingan yang baik dari awal hingga akhir penulisan laporan akhir ini, tidak lupa juga penulis mengucapkan terimakasih kepada Bapak dan Ibu dosen serta staff tata usaha Fakultas Pariwisata Universitas Udayana yang telah membantu penulis dalam hal administrasi. Penulis juga mengucapkan terimakasih kepada seluruh pihak Four Points by Sheraton Bali, Seminyak beserta seluruh karyawan Four Points by Sheraton Bali Seminyak dalam partisipasinya untuk mengisi kuesioner dan membantu dalam pengumpulan data. Terima kasih juga kepada keluarga, sahabatsahabat, dan teman-teman Diploma IV Pariwisata yang telah mendukung dan memberikan motivasi kepada penulis dalam penyelesaian laporan akhir ini.

\section{DAFTAR PUSTAKA}

Abdullah, Ma'ruf (2015) Metodologi Penelitian Kuantitatif. Yogyakarta : Aswajaya Pressindo

Azim, Muhammed dan Taib Dora (2016). "Perceived Organizational Support And Organizational Citizenship Behavior: The Mediating Role Of Psychological Capital". Malaysia University Jurnal Of Psychology. 15 (2). pp. 1-16

Eisenberger et.al. (2002) "Perceived Organizational Support : A Review Of The Literature". Delaware University Journal of Applied Psychology 2002, 84 (4), 698-714. 
Ghozali (2011) Aplikasi Analisis Miltivariate Dengan Program SPSS. Semarang : Badan Penerbit Universitas Diponogoro

Greenberg J, Baron A.R. (2003) Organizational Behavior In Organization : Understanding And Managing The Human Side Of Work. Canada : Prentice Hall

Hasibuan, Malayu S.P. (2002) Manajemen Sumber Daya Manusia, Edisi Revisi. Jakarta :Bumi Aksara

Julanda, Wayan Agus. (2018). Pengaruh Perceived Organizational Support Terhadap Organizational Citizenship Behavior Karyawan Di Intercontinental Bali Resort. Skripsi. Fakultas Pariwisata Universitas Udayana, Denpasar.

Novliadi (2007). Organizational Citizenship Behavior Karyawan Ditinjau dari persepsi terhadap kualitas interaksi atasan bawahan dan persepsi terhadap dukungan organisasional. Thesis. Fakultas Kedokteran Universitas Sumatera Utara, Medan.

Podaskoff.dkk. (2000) “Organizational Citizenship Behavior : A Critical Review of Theorical and Empirical Literature and Suggestion For Future Research". Iowa University Journal of Management, 26(3), pp. 1-51.

Purwadarminta (1986) Kamus Umum Bahasa Indonesia. Jakarta : Balai Pustaka

Rohmad, Supriyanto. (2015) Pengantar Statistika. Yogyakarta : Kalimedia

Romie Priyastama. (2017) Buku Sakti SPSS (Pengolahan Data dan Analisis). Bantul : Pt. Anak Hebat Indonesia

Tambe Sukhada , Shanker Meera (2014) "A Study Of Organizational Citizenship Behaviour (OCB) And Its Dimensions: A Literature Review". International Research Journal of Business and Management - IRJBM. Vol No.1, Page 67-73

Zhang. Deww. (2010) Organizational Citizenship Behavior. White Paper. University of Auckland : New Zealand. 